\title{
The world's biggest hotel companies. Old trends and new tendencies
}

\begin{abstract}
Many hotels are owned by a few dozen so-called hotel chains or hotel systems. The rapid growth of big hotel companies can be regarded as proof of the entrance of hotel systems into the globalisation phase. Since 2006, companies from the People's Republic of China (PRC) have been among the world's top hotel systems. This year can be considered as the symbolic beginning of a new stage in the history of the largest hotel systems. This paper shows two main trends. On the one hand, the processes that could be observed in the market of the major global hotel systems from the 1990s are still discernible (for example, the position of the so-called hotel megasystems). On the other hand, new trends have come to the fore in recent years, notably the emergence of systems from the People's Republic of China among the world's largest hotel systems.
\end{abstract}

Keywords

Hospitality $\bullet$ hotel megasystems $\bullet$ Chinese hotel chains

(C) University of Warsaw - Faculty of Geography and Regional Studies

\section{Andrzej Kowalczyk}

Department of Geography of Tourism \& Recreation

Institute of Socio-Economic Geography \& Spatial Management

Faculty of Geography \& Regional Studies

University of Warsaw

Poland

e-mail: akowalczyk@uw.edu.pl

Received: 30 September 2014

Accepted: 18 August 2015
Introduction

A large proportion of hotels worldwide are owned by a few dozen so-called chains or systems, many of which operate on all continents. According to S. Formica (1996), and in line with the business life-cycle theory, their expansion results from the hospitality sector reaching the stage where continued development can be ensured not only by the consolidation of hotels which previously operated in isolation, but also by the capturing of new markets. Therefore, the growth of hotel systems can be regarded as proof of the hotel companies entering the phase of globalisation rather than monopolisation.

The literature on hospitality services uses such notions as 'chain', 'brand', 'system' and 'hotel group'. For the purposes of the present study, the terms 'hotel system' and 'hotel group' are used interchangeably. As a rule, these denote many of the hotels under joint management, which maintain uniform standards, offer a similar range of services, pursue a common economic policy, and use a shared booking system and common logo.

The emergence of hotel systems on the hospitality services market is primarily a result of the drive to concentrate ownership, typical of highly developed economies in capitalist countries. In parallel, with the rapidly growing tourist traffic, big hotel systems can better satisfy the increasing demand for hotel services since, with their extensive capital resources, they are able to build new facilities, modernise the existing ones, develop accompanying services, and so on, in a relatively short time. As a result, they can offer cheaper and more efficient services in the conditions of rapidly growing tourist traffic. For this reason, too, large hotel systems are considered a major source of innovation in the provision of hospitality services, such as introducing state-of-the-art booking systems, non-cash settlements, launching new services for clients and new technological solutions in catering, and so on.

The database for statistical analysis which is a part of this article contains information about number of rooms for the biggest hotel systems worldwide. The figures used for analysis are published regularly in summer issues of the journal "Hotels" for the 300 biggest global hotel chains. But the data sets selected for analysis were chosen only for the 20 biggest hotel companies. The number of hotel chains used for analysis may be disputed, but in the author's opinion this sample mostly constitutes hotel companies of global importance.

Stages in the recent history of the development of global hotel systems

Until recently, five stages could be identified in the history of hotel systems: the period up until 1950 (stage 1); the years 19501970 (stage 2); the years 1970-1990 (stage 3); the years 19901996 (stage 4), and the post-1997 period (stage 5).

The development of hotel chains began in 1907 when Ellsworth M. Statler opened a hotel in Buffalo (USA), which was the first hotel in the Hotel Statler Company, Inc. chain. If Ellsworth M. Statler should be credited as the founder of the first hotel system, Conrad $\mathrm{N}$. Hilton was the one who put these chains on a footing which has existed until the present day. Although Hotel Statler Company, Inc., Hilton Hotel, Inc. and Canadian Pacific Hotels came from North America, in stage 1 hotel chains started to appear in Europe and Japan. Some of them (in Japan, for example) were set up by railway companies. It is difficult to pinpoint the exact moment of transition from stage 1 to stage 2 in the history of hotel systems. 
It could be just before World War II broke out (for example, when Travelodge Hotels, Inc. was created) or in the early years following the war (for example, the "Holiday Inn" hotel was opened in 1952 in Memphis, USA). The phenomenon which marked the beginning of stage 2 was the appearance of low budget hotels for drivers and tourists travelling by car. Establishing the date when stage 2 finished and stage 3 began is similarly difficult. It could be in 1967 (the year of opening of "Novotel" in Lille, France), 1968 (the takeover of the Sheraton Corp. chain by ITT) or 1972 (the opening of the first Marriott Corp. hotel outside the USA). One very important characteristic of stage 3 was the overseas expansion of the American hotel systems which had earlier operated exclusively (or almost) in the USA (Kowalczyk 2007).

Since the issues of the periodisation of hotel systems worldwide and the hotel sector expansion in the context of globalisation have already been tackled in the literature (CrawfordWelch 1992; Littlejohn, Roper 1991; Alexander, Lockwood 1996), the present study focuses predominantly on the processes that took place post-1990.

Although stage 4 was largely a continuation of stage 3 (when more and more major hotel systems began to operate globally), several new phenomena could be observed while the stage was in progress: (a) the amalgamation of hitherto independent systems into one huge system (although with decentralised management); (b) the opening up of former socialist countries in Central-Eastern Europe, post-Soviet Union countries and China to Western investors; (c) the failure or even spectacular collapse of several large systems; (d) the distinct crisis of the concept of systems associated with airlines.

The transition from stage 4 to stage 5 took place in 19961997. The entrance of the hotel systems into a new development phase came rather unexpectedly and for over a year experts tended to believe that these newly observable changes were temporary. However, it was later agreed that the developments that took place post-1997 justify the opinion that this particular year marked the beginning of a new phase in the development of the global hotel market. The event that warrants treating the late 1990s differently than the first half of the decade was the emergence of big hotel systems (earlier, the process only involved smaller systems), the so-called REITs - real estate investment trusts. One of the REITs which virtually shook the global market of hotel systems was the Starwood Lodging Trust, part of the Starwood Capital Group founded by Barry Sternlicht in 1991. While its founder had originally focused on taking over individual hotels, in 1997 he made a simultaneous bid to take over ITT Sheraton Corp. (ranked $7^{\text {th }}$ globally in 1996) and Westin Hotels \& Resorts (ranked $17^{\text {th }}$ in 1996). Since both of these moves proved successful, in 1997 the newly founded Starwood Hotels \& Resorts appeared in the group of the world's largest hotel systems, and was ranked $7^{\text {th }}$ globally. Another huge company with a previous specialisation in real estate transactions, which in 1997 was ranked among the largest hotel systems in the world, was the Patriot American Hospitality Corp. Following the takeover of the small Carefree Resorts system, in late 1997 it bought the USowned Wyndham Hotels \& Resorts Corp. (ranked $27^{\text {th }}$ globally in 1996). After the takeover of several smaller brands and a number of independent hotels, the newly launched Patriot American Hospitality, Inc./Wyndham International, Inc. chain reached as high as $12^{\text {th }}$ place in the global ranking of the largest hotel systems.

Another phenomenon typical of this stage (and already observable at stage 4) was the continued merging of hotel systems into larger groups. While earlier this was mainly true for smaller systems being taken over by larger ones, in the late $20^{\text {th }}$ century similarly sized systems started to amalgamate. ${ }^{1}$ The

${ }^{1}$ Previously, this phenomenon could only be observed when Hospitality Franchise Systems was founded in 1990 . following examples of such spectacular consolidation events can be quoted:

- $\quad$ the 1997 merger of Hilton Hotels Corp. and Hilton International Hotels, and the subsequent takeover of the Doubletree Hotels, Suites, Resorts \& Clubs system in 1998 and of Promus Hotel Corp. in 1999;

- $\quad$ the 1997 takeover of Renaissance Hotels International by Marriott International, Inc., and the 1998 takeover of the USowned system, Ritz-Carlton Hotel Co.;

the 2006 merger of Cendant Corp. (until 1997 operating as Hospitality Franchise Systems) and Wyndham Hotels \& Resorts, which launched a new system named Wyndham Worldwide.

These mergers and acquisitions resulted in the emergence of huge hotel groups which could justifiably be termed hotel megasystems (Kowalczyk 2012). They are characterised by: (a) large size, measured by the number of rooms (although the limit is difficult to set, they normally have more than 300,000 rooms); (b) well-developed organisational structure, which is largely connected with the earlier acquisitions of other hotel systems and brands; (c) pursuing operations on several continents, and (d) conducting operations in other sectors of the economy (usually associated with tourism or the real estate market), and (e) the considerable gap between them and other hotel systems from the group of the largest systems worldwide. In light of the above, in 2014 such megasystems certainly included Hilton Worldwide, Marriott International, Inc. InterContinental Hotels Group PIc., Wyndham Hotel Group, and possibly Choice Hotels International, Inc. and AccorHotels (Table 1).

In the development of hotel systems around the world, the year 2006 saw the transition from stage 5 to stage 6 . The event which can be considered as the symbolic beginning of the new stage was the inclusion of a system from the People's Republic of China (PRC) in the group of the largest global hotel systems. This was the state-owned company, Jin Jiang International Hotels, which was ranked $22^{\text {nd }}$ in $2005,29^{\text {th }}$ in $2004,35^{\text {th }}$ in $2003,47^{\text {th }}$ in $2002,58^{\text {th }}$ in 2001 , and $51^{\text {st }}$ in 2000 (Kowalczyk 2006) ${ }^{2}$.

Jin Jiang International Hotels being ranked $17^{\text {th }}$ among the world's largest hotel systems in 2006 was no coincidence but a result of the rapid expansion of Chinese hotel systems. Although until 2008 it was the only system from the PRC in the group of the 20 largest hotel systems in the world (operating under a different name), in 2009 Shanghai Jin Jiang International Hotel Group Co. Ltd. was joined by Home Inns \& Hotel Management, along with the 7 Days Group and the China Lodging Group in 2011, and the GreenTree Inns Hotel Management Group in 2012 (Table 2). As a result, in 2014 the group of the largest 20 hotel systems globally comprised systems from the United States (12 systems) followed by the PRC (with five systems), with France, the United Kingdom and Spain (one system each) ranked behind those countries. Between them, in 2014 the Chinese systems owned $21.5 \%$ of the rooms available in the 20 largest hotel systems worldwide, compared to $15.2 \%$ in $2013,13.0 \%$ in $2012,9.7 \%$ in 2011 , a mere $3.8 \%$ in 2010 and $3.1 \%$ in 2009 .

Trends visible in the development of the biggest global hotel systems in 1990-2014

The entry of hotel systems from the PRC into the group of the world's largest systems undoubtedly shook this segment of the hospitality market due to the ousting of some systems from the United States and Europe. The question should be posed, however, as to whether the tendencies observable post-2006 that is, in stage 7 of the development of the largest hotel systems

${ }^{2}$ In 1995-1999, the Jin Jiang International Hotel Management Corporation was successively ranked $65^{\text {th }}, 64^{\text {th }}, 81^{\text {st }}, 97^{\text {th }}$ and $51^{\text {st }}$ (Kowalczyk 2006, 11). 
MISCELLANEA GEOGRAPHICA - REGIONAL STUDIES ON DEVELOPMENT

Vol. $19 \cdot$ No. 4 • 2015 • pp. 26-33 • ISSN: 2084-6118 • DOI: 10.1515/mgrsd-2015-0020

Table 1. The world's biggest hotel companies in 2014.

\begin{tabular}{|c|c|c|c|c|}
\hline \multirow{2}{*}{ Rank } & \multirow{2}{*}{ Company } & \multirow{2}{*}{ Country } & \multicolumn{2}{|c|}{ Number } \\
\hline & & & Rooms & Hotels \\
\hline 1 & Hilton Worldwide & United States & 715,062 & 4,322 \\
\hline 2 & Marriott International, Inc. & United States & 714,765 & 4,175 \\
\hline 3 & InterContinental Hotels Group Plc. & United Kingdom & 710,295 & 4,840 \\
\hline 4 & Wyndham Hotel Group & United States & 660,826 & 7,645 \\
\hline 5 & Choice Hotels International, Inc. & United States & 500,000 & 6,300 \\
\hline 6 & AccorHotels & France & 482,296 & 3,717 \\
\hline 7 & Plateno Hotels Group & PRC & 442,490 & 3,023 \\
\hline 8 & Starwood Hotels \& Resorts Worldwide, Inc. & United States & 354,225 & 1,222 \\
\hline 9 & Shanghai Jin Jiang International Hotel Group Co. & PRC & 352,538 & 2,910 \\
\hline 10 & Best Western International, Inc. & United States & 303,522 & 3,931 \\
\hline 11 & Home Inns \& Hotels Management & PRC & 296,075 & 2,609 \\
\hline 12 & China Lodging Group & PRC & 209,955 & 1,995 \\
\hline 13 & Carlson Rezidor Hotel Group & United States & 172,234 & 1,092 \\
\hline 14 & Hyatt Hotels Corp. & United States & 155,265 & 587 \\
\hline 15 & GreenTree Inns Hotel Management Group & PRC & 142,038 & 1,580 \\
\hline 16 & G6 Hospitality & United States & 115,461 & 1,229 \\
\hline 17 & Meliá Hotels International & Spain & 98,829 & 377 \\
\hline 18 & Magnuson Hotels Worldwide & United States & 96,225 & 1,176 \\
\hline 19 & Westmont Hospitalty Group & United States & 92,343 & 706 \\
\hline 20 & LQ Management & United States & 86,500 & 867 \\
\hline
\end{tabular}

Source: based on the data published in "Hotels" journal in July/August 2015.

worldwide - are different from the trends visible previously. To answer this question, the data compiled for the entire 1990-2014 period were statistically analysed and the following parameters were computed:

- $\quad$ For each year, the product of the number of rooms in the largest system (1 $1^{\text {st }}$ place in the ranking) and the number of rooms in the smallest system of the group of the world's largest hotel systems $\left(20^{\text {th }}\right.$ place in the ranking) was calculated;

- $\quad$ For each year, the index of changes in the number of rooms available from the world's 20 largest hotel systems was calculated, with the number of rooms in 1990 adopted as 100;

- For each year, the arithmetical mean of the number of rooms for the series comprising all of the 20 systems was calculated;

- For each year, the standard deviation was calculated for the series comprising the number of rooms in all of the 20 systems;

- For each year, the coefficient of variation was calculated for the series comprising the number of rooms in all of the 20 systems;

- For each year, skewness was calculated for the series comprising the number of rooms in all of the 20 systems.

The results of this exercise and the total number of rooms in each year for the 20 largest hotel systems are shown in Table 3.

The first conclusion that can be drawn following even a cursory analysis of the data provided in Table 3 is that in the period 1990-2014 the number of rooms owned by the 20 largest hotel systems considerably increased, from $2,156,469$ to
$6,700,944$. With the year 1990 adopted as 100 , the growth index for 2014 was as much as 311 . It should also be noted that the global recession that has lasted now for several years has not crippled this upward trend.

The second conclusion, partly concerning the dispersion observable within the analysed group, suggests that the ratio of the number of rooms between the largest and the smallest of the analysed systems varied considerably in the period 1990-2014. While it was similar in 1990 and 2014 (9.2 and 8.2), for a long time it remained within the 12-15 range, reaching 17.0 in 1995. This can be explained by the emergence of the aforementioned hotel megasystems in the early 1990s. This trend is typified by Hospitality Franchise Systems, Inc. ${ }^{3}$, formed in 1990 following the merger of Howard Johnson International, Inc. and part of Ramada Franchise Systems, Inc., which, after the acquisition of Days Inn of America, Inc. in 1992 became the largest hotel system globally; their position was strengthened even further in the following years due to mergers with Super 8 Motels, Inc. (1993), Villager Lodge Franchise Systems, Inc. (1994), Knights Franchise Systems, Inc. (1995) and the acquisition of Travelodge from the bankrupting Forte Plc. (1996) ${ }^{4}$. Hospitality Franchise Systems, Inc. is not, however, the sole example of the consolidation trends in the group of the world's largest hotel systems that first came to be observed around that time. Other examples of this phenomenon include the launch of the present Starwood Hotels \& Resorts

${ }^{3}$ Founded on the initiative of Henry Silverman, an executive at The Blackstone Group, an investment bank. Available from: <http://www.referenceforbusiness.com/ history2/90/Hospitality-Franchise-Systems-Inc.html>. [03.03.2012].

${ }^{4}$ In 1997, Hospitality Franchise Systems, Inc. was renamed Cendant Corp., which became the Wyndham Hotel Group in 2006, following the merger with Wyndham Hotels \& Resorts. 
Table 2. Growth of the top PRC hotel systems in 2006-2014

\begin{tabular}{|c|c|c|c|c|}
\hline Year & & $\begin{array}{l}\text { Rank on the list } \\
\text { of the top global } \\
\text { hotel systems }\end{array}$ & $\begin{array}{l}\text { Number of } \\
\text { rooms }\end{array}$ & $\begin{array}{l}\text { Total number of rooms in the top } \\
\text { Chinese hotel systems as a share } \\
\text { of the number of rooms in the } 20 \\
\text { biggest global hotel systems }\end{array}$ \\
\hline 2006 & Jin Jiang International Hotels & 17 & 53,552 & 1.2 \\
\hline 2007 & $\begin{array}{l}\text { Shanghai Jin Jiang International Hotel } \\
\text { Group Co. Ltd. }\end{array}$ & 17 & 68,797 & 1.5 \\
\hline 2008 & $\begin{array}{l}\text { Shanghai Jin Jiang International Hotel } \\
\text { Group Co. Ltd. }\end{array}$ & 13 & 80,164 & 1.6 \\
\hline \multirow{3}{*}{2009} & $\begin{array}{l}\text { Shanghai Jin Jiang International Hotel } \\
\text { Group Co. Ltd. }\end{array}$ & 13 & 89,251 & \multirow{3}{*}{3.1} \\
\hline & Home Inns \& Hotel Management & 19 & 71,671 & \\
\hline & \multicolumn{2}{|l|}{ TOTAL } & 160,922 & \\
\hline \multirow{3}{*}{2010} & $\begin{array}{l}\text { Shanghai Jin Jiang International Hotel } \\
\text { Group Co. Ltd. }\end{array}$ & 12 & 107,019 & \multirow{3}{*}{3.8} \\
\hline & Home Inns \& Hotel Management & 13 & 93,898 & \\
\hline & TOTAL & & 200,917 & \\
\hline \multirow{5}{*}{2011} & Shanghai Jin Jiang International Hotels & 9 & 193,334 & \multirow{5}{*}{9.7} \\
\hline & Home Inns \& Hotels Management & 10 & 176,824 & \\
\hline & 7 Days Group & 15 & 94,684 & \\
\hline & China Lodging Group & 20 & 73,600 & \\
\hline & TOTAL & & 538,442 & \\
\hline \multirow{6}{*}{2012} & Shanghai Jin Jiang International Hotels & 9 & 214,796 & \multirow{6}{*}{13.0} \\
\hline & Home Inns \& Hotels Management & 10 & 214,070 & \\
\hline & 7 Days Group Holdings & 14 & 133,597 & \\
\hline & China Lodging Group & 16 & 113,650 & \\
\hline & GreenTree Inns Hotel Management Group & 18 & 96,800 & \\
\hline & TOTAL & & 772,813 & \\
\hline \multirow{6}{*}{2013} & Home Inns \& Hotels Management & 9 & 262,321 & \multirow{6}{*}{15.2} \\
\hline & $\begin{array}{l}\text { Shanghai Jin Jiang International Hotel } \\
\text { Group Co. }\end{array}$ & 10 & 235,461 & \\
\hline & Plateno Hotels Group & 12 & 165,446 & \\
\hline & China Lodging Group & 13 & 152,879 & \\
\hline & GreenTree Inns Hotel Management Group & 16 & 110,662 & \\
\hline & \multicolumn{2}{|l|}{ TOTAL } & 926,769 & \\
\hline \multirow{6}{*}{2014} & Plateno Hotels Group & 7 & 442,490 & \multirow{6}{*}{21.5} \\
\hline & $\begin{array}{l}\text { Shanghai Jin Jiang International Hotel } \\
\text { Group Co. }\end{array}$ & 9 & 352,538 & \\
\hline & Home Inns \& Hotels Management & 11 & 296,075 & \\
\hline & China Lodging Group & 12 & 209,955 & \\
\hline & GreenTree Inns Hotel Management Group & 15 & 142,038 & \\
\hline & TOTAL & & $1,443,096$ & \\
\hline
\end{tabular}

Source: author's calculation based on data published in "Hotels" journal for 2007-2015 
MISCELLANEA GEOGRAPHICA - REGIONAL STUDIES ON DEVELOPMENT

Vol. $19 \cdot$ No. 4 • 2015 • pp. 26-33 • ISSN: 2084-6118 • DOI: 10.1515/mgrsd-2015-0020

Table 3. Statistical characteristics of the 20 biggest global hotel companies in 1990-2014

\begin{tabular}{|c|c|c|c|c|c|c|c|}
\hline \multirow[b]{3}{*}{ Year } & \multirow[b]{3}{*}{$\begin{array}{c}\text { Number of } \\
\text { rooms }\end{array}$} & \multirow{3}{*}{$\begin{array}{l}\text { No. of rooms in the } \\
\text { biggest hotel company } \\
\text { divided by no. of rooms } \\
\text { in the smallest hotel } \\
\text { company }\end{array}$} & \multirow{3}{*}{$\begin{array}{l}\text { Index of } \\
\text { changes } \\
(1990=100)\end{array}$} & \multicolumn{4}{|c|}{ Selected statistical measures } \\
\hline & & & & \multirow{2}{*}{$\begin{array}{c}\text { Arithmetic } \\
\text { mean } \\
(\mu)\end{array}$} & \multicolumn{2}{|c|}{ Measures of dispersion } & \multirow[b]{2}{*}{$\begin{array}{c}\text { Skewness } \\
\text { (v) }\end{array}$} \\
\hline & & & & & $\begin{array}{c}\text { Standard } \\
\text { deviation } \\
\text { (ठ) }\end{array}$ & $\begin{array}{l}\text { Coefficient of } \\
\text { variation } \\
\text { (V) }\end{array}$ & \\
\hline 1990 & $2,156,469$ & 9.2 & 100 & $107,823.5$ & 79626.3 & $73.80 \%$ & 1.457669 \\
\hline 1991 & $2,332,724$ & 11.6 & 108 & $116,636.2$ & 94465.7 & $81.00 \%$ & 1.107185 \\
\hline 1992 & $2,454,503$ & 12.9 & 114 & $122,725.2$ & 105227.5 & $85.70 \%$ & 1.132056 \\
\hline 1993 & $2,544,160$ & 13.7 & 118 & $127,208.0$ & 109362.3 & $86.00 \%$ & 1.234265 \\
\hline 1994 & $2,657,463$ & 14.5 & 123 & $132,873.2$ & 117364.9 & $88.30 \%$ & 1.312962 \\
\hline 1995 & $2,752,759$ & 17.0 & 128 & $137,638.0$ & 132898.4 & $96.60 \%$ & 1.565061 \\
\hline 1995 & $2,890,911$ & 15.2 & 134 & $144,545.6$ & 135023.1 & $93.40 \%$ & 1.303690 \\
\hline 1997 & $3,209,735$ & 14.4 & 149 & $160,486.8$ & 147892.1 & $92.20 \%$ & 1.111577 \\
\hline 1998 & $3,374,960$ & 14.7 & 157 & $168,748.0$ & 152322.8 & $90.30 \%$ & 1.089327 \\
\hline 1999 & $3,619,245$ & 14.9 & 168 & $180,962.3$ & 163711.0 & $90.50 \%$ & 0.899703 \\
\hline 2000 & $3,784,555$ & 13.1 & 175 & $189,227.8$ & 169819.2 & $89.70 \%$ & 0.828581 \\
\hline 2001 & $3,971,152$ & 13.5 & 184 & $198,557.6$ & 176476.9 & $88.90 \%$ & 0.829731 \\
\hline 2002 & $4,071,543$ & 13.4 & 189 & $203,577.2$ & 178516.8 & $87.70 \%$ & 0.779073 \\
\hline 2003 & $4,125,110$ & 13.4 & 191 & $206,255.5$ & 184129.8 & $89.30 \%$ & 0.757526 \\
\hline 2004 & $4,270,125$ & 13.4 & 198 & $213,506.3$ & 181285.0 & $84.90 \%$ & 0.757526 \\
\hline 2005 & $4,467,916$ & 11.9 & 207 & $223,395.8$ & 200072.5 & $89.60 \%$ & 0.641202 \\
\hline 2006 & $4,532,461$ & 11.6 & 210 & $226,623.1$ & 201408.0 & $88.90 \%$ & 0.670052 \\
\hline 2007 & $4,704,078$ & 10.6 & 218 & $235,203.9$ & 200792.4 & $85.40 \%$ & 0.717350 \\
\hline 2008 & $4,899,337$ & 10.2 & 227 & $244,966.9$ & 214195.9 & $87.40 \%$ & 0.758678 \\
\hline 2009 & $5,131,290$ & 9.9 & 238 & $256,564.5$ & 222204.3 & $86.60 \%$ & 0.767007 \\
\hline 2010 & $5,270,984$ & 9.6 & 244 & $263,549.2$ & 225687.6 & $85.60 \%$ & 0.771350 \\
\hline 2011 & $5,549,108$ & 8.9 & 257 & $292,058.3$ & 225405.9 & $77.18 \%$ & 0.675985 \\
\hline 2012 & $5,931,692$ & 7.7 & 275 & $296,584.6$ & 219607.3 & $74.05 \%$ & 0.799523 \\
\hline 2013 & $6,094,592$ & 7.2 & 283 & $304,729.6$ & 220717.5 & $69.62 \%$ & 0.805525 \\
\hline 2014 & $6,700,944$ & 8.2 & 311 & $335,047.2$ & 228568.3 & $68.22 \%$ & 0.665084 \\
\hline
\end{tabular}

Source: author's calculation based on data published in "Hotels" journal for 1991-2015

Worldwide, Inc. system or the takeover of Inter-Continental Hotels \& Resorts by the brewing company Bass International Holdings Plc., the then owner of Holiday Inn Worldwide. Since these sensational mergers and acquisitions came to an end some time ago, it could be surmised that they to some extent reflected the trends observable in the global real estate market at the turn of the century (and followed by the financial crisis later), resulting in the tangible consolidation of certain systems which evolved into megasystems. To sum up, based on the measure showing the ratio of the number of rooms in the largest and the smallest systems of those covered by the study, it can be concluded that there was an upward trend visible approximately until the mid1990s (when the disparities between the world's 20 largest hotel systems became even wider). At that point, the situation had been stabilising since the second half of the decade, whereas later (post 2000) the difference in size between the largest and the smallest system began to fall systematically, reaching a level in 2014 which was even lower than that in 1990.

The third conclusion - associated with the average size of the system - suggests that the systems are becoming increasingly bigger. For 1990, the arithmetical mean calculated on the basis of data showing the number of rooms in the world's largest hotel systems was over 107,823 rooms, while by 2014 it had increased to over 335,047 rooms.

The fourth and fifth conclusions are related to the trends visible within the analysed group of the world's largest hotel systems and also make reference to the second conclusion. Based on the calculated measures of variation (standard deviation and coefficient of variation), it can be concluded that the internal differences within the analysed group were nearly the same at the end of the surveyed period as they were at the beginning of the period in question. Whereas in 1990 the coefficient of variation $\vee$ was $73.80 \%$, between 1991 and 2010, it did not fall below $80 \%$; its value reached over $95 \%$ in some years (96.60\% in 1995), and unexpectedly fell to $69.62 \%$ and $68.22 \%$ in 2013 and 2014, respectively.

The sixth conclusion coincides with two earlier ones and pertains to the information provided by the analysis of skewness calculated for each year in the 1990-2014 period. According to the adopted interpretation, the absolute value of the skewness 
increases as asymmetry grows. In the asymmetric distribution, the value of the coefficient is $Y<0$, and the distribution is skewed to the left (negative skew), which means that the frequencies are concentrated around the high values of the variable. In contrast, with the coefficient $y>0$, the distribution is skewed to the right, which means that most frequencies in the distribution are concentrated around the low values of the variable.

It is sometimes assumed that values in the range -1.5 to 1.5 denote a symmetrical distribution. The data presented in Table 3 indicate that each year of the 1990-2014 period was characterised by a right-skewed distribution (positive skew), although the skewness values for individual years differed quite considerably. The skewness coefficient was highest in 1990 (1.457669) and 1995 (1.565061); in 2000 it dropped (0.8285581), reaching a minimum in $2005(0.64120200)$, and increasing again in the following years to 0.665084 in 2014 , but not so distinctly as was the case in the early 1990s. By attempting an interpretation of the coefficients listed in Table 3 and juxtaposing them with the data showing the number of rooms, it might be concluded that in the mid-1990s, among the major hotel systems of the world, there were clearly more systems with a relatively smaller number of rooms, coupled with the parallel very strong position of the first system in the ranking (in 1995 Hospitality Franchise Systems, Inc. totalled as many as 509,500 rooms, while the second-ranked Holiday Inn Worldwide had 369,738 rooms, and the third largest system, Best Western International, Inc., 'only' had 282,062). In the succeeding years, the difference between the first two and subsequent systems gradually diminished until post-2000, when megasystems appeared in the group of the world's largest hotel systems. Therefore, this conclusion, just as the two earlier ones (fourth and fifth), indicates that in some aspects 1995 was of critical importance for the analysed period, a year which was not without reason regarded as the final, decadent year of a stage (stage 5) in the development of hotel systems (Kowalczyk 2006).

New trends in the market of the biggest global hotel systems - hotel systems from the People's Republic of China among the "big players"

Two main conclusions can be drawn so far: on the one hand, the trends that could be observed in the market of the major global hotel systems in the 1990s are still discernible (such as the increasingly strong role of the hotel megasystems, for example), and on the other hand new trends have come to the fore in recent years - that is, the emergence of systems from the People's Republic of China among the world's largest hotel systems

The economic recession in the United States starting in December 2007 and ending in June 2009 has imposed severe challenges for all kinds of industries. In the hotel industry, demand is derived from business and tourist-based travellers, whose spending is highly influenced by the strength of the economy (Fig. 1). So, in many countries the hotel industry has faced adverse conditions due to a reduction in the occupancy rate, which has resulted in a reduction in the revenues of the hotels.

But at the same time the Chinese economy was booming, as was the Chinese hospitality industry. Between 2007 and 2009 the share of the number of rooms in Chinese hotel systems in the top 20 global hotel companies increased from $1.5 \%$ to $3.1 \%$. This boom was observed in the following years too, and in 2014 the share reached $21.5 \%$ (Fig. 2).

Let us look in more detail at the leading Chinese hotel systems.

Plateno Hotels Group Co. Ltd. (before 2013 the name of the company was 7 Days Group Holdings or 7 Days Group Holdings Ltd.) was formed in 2005 in Guangzhou as a system specialising in budget hotels. Thanks to the funding provided by Warburg Pincus LLC (United States) in 2006, Merrill Lynch Wealth

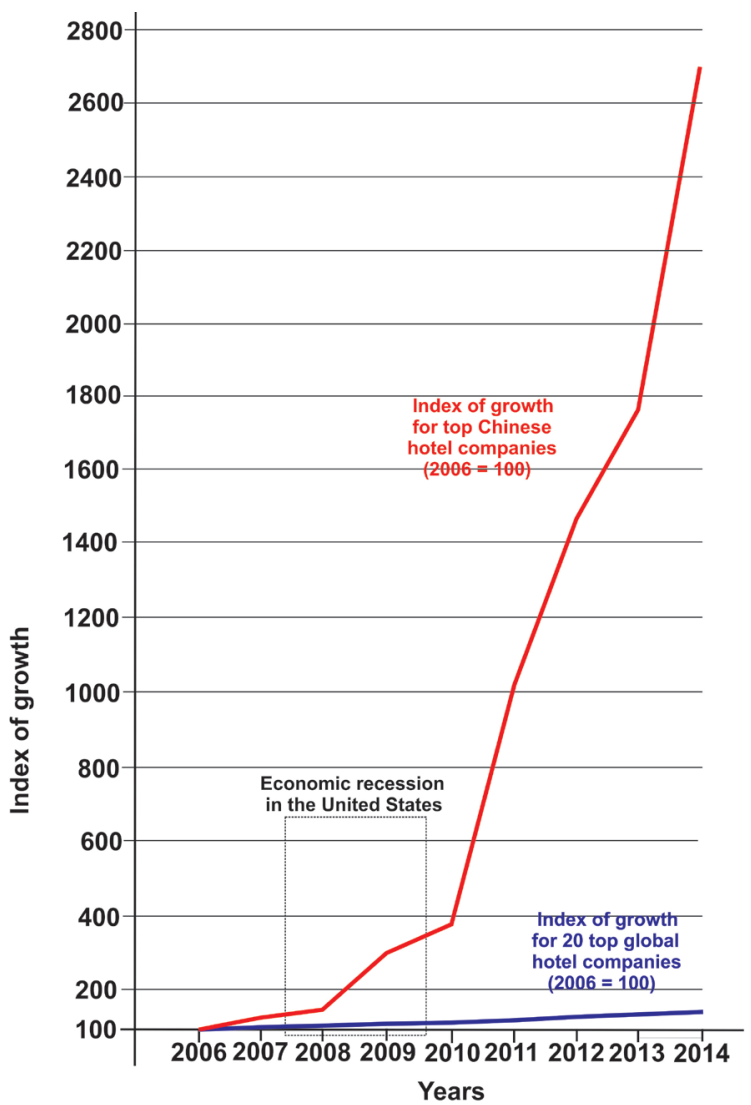

Figure 1. Index of growth for the top 20 global hotel companies and Chinese hotel companies in the period 2006-2014 (by number of rooms)

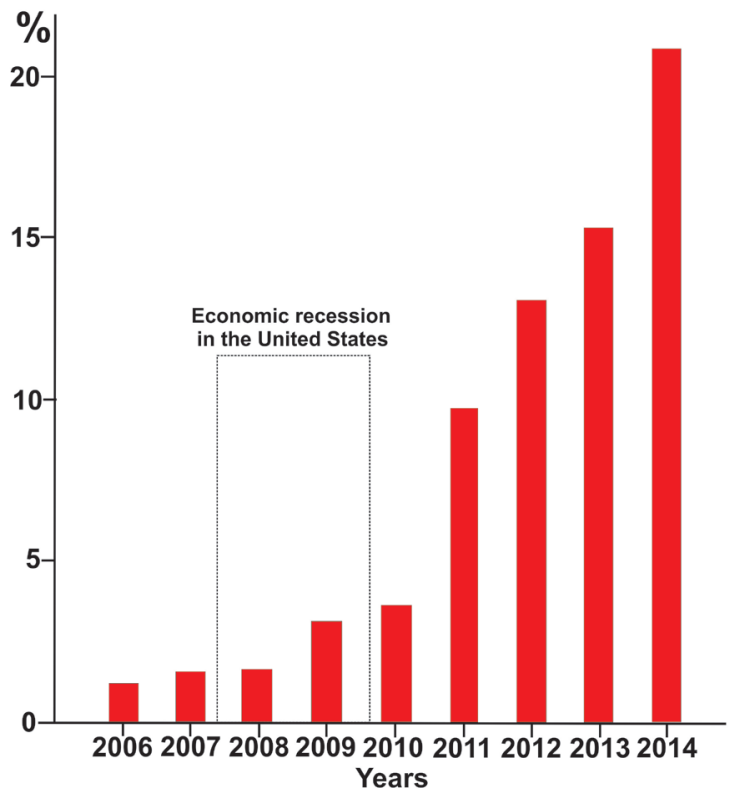

Figure 2. Total number of rooms in the Chinese hotel companies as a share of the number of rooms in the world's 20 biggest hotel systems in 2006-2014 
Management (United States), Deutsche Bank (Germany) and Warburg Pincus LLC in 2007, and Actis Capital (United Kingdom) in 2008, 7 Days Group Holdings Ltd. became the first large hotel system in the PRC specialising in the budget segment and in 2009 it was listed on the New York Stock Exchange. ${ }^{5}$

In July 2013, 7 Days Group Holdings Ltd. was taken over by the newly-founded Plateno Hotels Group Ltd., which, in addition to 7 Days Group Holdings Ltd.'s ownership (30\% stake), was co-owned by investment funds from Carlyle Investment Group and Sequoia Capital China ( $20 \%$ and $15 \%$ stake, respectively), and by Nanyan Zheng (alias Alex Zheng), co-founder and cochairman ${ }^{6}$ of Plateno Hotels Group Ltd. (10\% stake). In its plans for the coming years announced in summer 2013, Plateno Hotels Group Ltd. declared the launch of new brands (other than 7 Days Inn): Portofino Hotel (upscale), Lavande Hotel (midscale) and the coffee culture themed-hotel brand, James Joyce Coffetel, in addition to ZMAX Hotel, planned for the more distant future (Xiaozhuo 2013). These plans were realized and nowadays (August 2015) Plateno Hotels Group Co. Ltd. consists of brands from luxury hotels to budget hotels. The luxury brands are Maison, Albar, Hotel Portofino and H12. The midscale-level brands are ZMAX, James Joyce Coffetel and Lavande, and the budget-level brands are 7 Days Premium and 7 Days Inn.

In the strategy of Plateno Hotels Group Co. Ltd. the primary goal is to be a leader in the lodging industry in Asia and globally. The first international hotel openings in Thailand and Malaysia in 2014 were followed in 2015 by the first three hotel openings in Indonesia with additional contracts signed in Indonesia, Laos, Sri Lanka, the Maldives, the Philippines and Australia. ${ }^{7}$

The second largest hotel system in the PRC in 2014, the Shanghai Jin Jiang International Hotel Group Co. system, is based in Shanghai but was operating in over 280 cities in 31 provinces, municipalities and autonomous regions of the PRC offering most rooms in hotels located in Shanghai and Beijing. ${ }^{8}$ The present Shanghai Jin Jiang International Hotel Group Co. (or rather Shanghai Jinjiang International Hotels Holdings Company Limited) was formed in 2003 as a subsidiary of the state-owned Jinjiang International (Group) Company Limited (which was probably established in 1995), the largest provider of tourist services in the People's Republic of China. One of the subsidiaries, Shanghai Jinjiang International Hotel Development Company Limited, has been listed on the Shanghai Stock Exchange since 1996, and the holding company, Shanghai Jinjiang International Hotels (Group) Company Limited, has been traded on the Hong Kong Stock Exchange since 2006. Shanghai Jin Jiang International Hotel Group Co. owns hotels in the PRC in addition to hotels in the special administrative regions of Hong Kong and Macau. The global aspirations of Shanghai Jin Jiang International Hotel Group Co. are manifested in the fact that, as of 31 December 2014, it also owned 350 hotels in the United States (totalling 64,947 rooms), as well as 39 hotels in the United Kingdom (with 43,952 rooms), 11 hotels in Russia (with 3,159 rooms), 11 hotels in the Netherlands (with 1,906 rooms), and hotels in India, Belgium, Canada, Ireland, Bosnia and Herzegovina, Kazakhstan, Belarus and Hungary. ${ }^{9}$ In addition to

${ }^{5}$ S. Shen (2008)

Available from: <http://en.wikipedia.org/wiki/7 Days_Inn>. [15.02.2014]

${ }^{6}$ With $\mathrm{He}$ Boquan as the second co-founder and co-chairman.

${ }^{7}$ Available from: <http://www.plateno-hotels.cc/en/about-us>. [25.08.2015]

${ }^{8}$ Shanghai Jin Jiang International Hotels (Group) Company Limited. Annual report 2014', Shanghai Jin Jiang International Hotels (Group) Company Limited, Shanghai. Available from: <http:/www.jiniianghotels.com.cn/UploadFiles/E_JJ13_AR.pdf>. [25.08.2015]

9'Shanghai Jin Jiang International Hotels (Group) Company Limited. Annual report 2014', Shanghai Jin Jiang International Hotels (Group) Company Limited, Shanghai. Available from: <http://www.jinjianghotels.com.cn/UploadFiles/E_JJ14_AR.pdf>. [25.08.2015] hospitality services, Shanghai Jin Jiang International Hotel Group Co. offers catering services as the owner of a restaurant chain with traditional Chinese cuisine, but also as the manager of fast food outlets owned by the Kentucky Fried Chicken, Café dé Coral and Yoshinoya chains. ${ }^{10}$

The third major Chinese hotel system in 2014 was Home Inns \& Hotels Management, Inc. (or Home Inns Group). Home Inns \& Hotels Management, Inc. is one of the top budget hotel chains in China; indeed, it was the first budget chain to be established in China. It was launched in $2002^{11}$ in Shanghai. In 2006 it was listed on NASDAQ in New York City, and in 2007 it acquired a 26-hotel Top Star chain. Initially, it specialised in budget hotels (with a $44 \%$ share of the budget hotel market in the PRC in $2008^{12}$ ), but in 2010 it launched a new branch, Yitel, which offered services typical of the mid- and upscale segments. The year 2011 saw a rapid development of the group, with the acquisition of the Motel 168 chain and its 297 motels. ${ }^{13}$ In the following year the total number of hotels incrased and the system was ranked first among Chinese hotel systems. However, by 2014 it was in third position.

The China Lodging Group Ltd. (or HuaZhu Hotels Group Ltd.) hotel system was launched in 2007 as an initiative of several Chinese companies incorporated in the British Virgin Islands in 2003 and 2006, subsidiaries of Powerhill. The system's first brands were the economy HanTing Express Hotel, followed by the midscale HanTing Hotel (later rebranded to HanTing Seasons Hotel and finally JI Hotel). As early as 2007, China Lodging Group Ltd. took over Yiju (Shanghai) Hotel Management Co. Ltd., while 2008 saw the launch of the budget hotel brand HanTing Hi Inn, later renamed to $\mathrm{Hi}$ Inn. All these measures proved a success as planned, and in 2010 China Lodging Group Ltd. was listed on NASDAQ. With new funding acquired in May 2012, China Lodging Group Ltd. bought a $51 \%$ stake in the midscale hotel chain Starway Hotels (Hong Kong), and in August of the same year it announced its intention to launch the Joya Hotel brand, which was put into effect in 2013. ${ }^{14}$

The last of the largest hotel systems in the PRC, GreenTree Inns Hotel Management Group, Inc., was formed in 2004 on the initiative of Alex Xu, who secured the funding of several US investment enterprises for his idea. The system, which specialises in budget hotels, is headquartered in Shanghai. GreenTree Inns Hotel Management Group, Inc. has seven brands: GreenTree Inns, GreenTree Inn Express, GreenTree Inn Shell, GreenTree Eastern, GreenTree Suites, GreenTree Alliance and GreenTree International Hotel.

\section{Summary}

To sum up what has been said about the largest hotel systems of the world, it should be noted that, in the last few years, parallel to the trends visible since the early 1990s - whereby the market was dominated by US-based hotel systems, some of which evolved into megasystems - a completely new trend developed, which was the emergence of hotel systems from the People's Republic of China.

It is worth noting that, of the latter, only Shanghai Jin Jiang International Hotel Group Co. is a state-owned enterprise, while the others are privately owned, and in many cases their formation

${ }^{10}$ Available from: <http://www.jinjianghotels.com.cn/en/Aboutus. aspx? cid=18\&id=2> [15.02.2014].

${ }^{11}$ Although the first hotel was founded by Ji Qi as early as 2001.

${ }^{12}$ Available from: <http://en.wikipedia.org/wiki/Home_Inn>. [15.02.2014].

${ }^{13}$ Available from: <http://phx.corporate-ir.net/phoenix.zhtml?c=203641\&p=irolhomeProfile>. [15.02.2014].

${ }^{14}$ In effect, China Lodging Group Ltd. has five brands: JI Hotel and Starway Hotel (midscale class), HanTing Hotel (economy class), Hi Inn (budget class) and Joya Hotel (upscale market) 
was inspired by Chinese who had lived out of the country for a considerable time (mostly in the United States). Another typical aspect of their operations is that they very clearly specialise in budget class hotels,$^{15}$ less frequently in the economy and midscale class, and very seldom run upscale hotels. One example of huge interest in budget class hotels is the new initiative undertaken by GreenTree Inns Hotel Management Group, Inc., which in 2013 resolved to launch a new brand (Vatica Hotel) incorporating 'minihotels' with $30-50$ rooms. ${ }^{16}$

\footnotetext{
${ }^{5}$ To hotel market analysts, the rapid development of the budget hotel industry in the PRC is reminiscent of the trend visible in the United States in the 1950s. Although the first budget hotel opened in 1996 under the brand of Jin Jiang Inn, the phenomenon started to grow in scale post-1999, when the Chinese government began to promote domestic tourism as a way to stimulate the economy. Other drivers fostering the expansion of budget hotels and motels included the organisation of the Summer Olympic Games in Beijing (2008) and the World Expo in Shanghai (2010). The continuing demand for budget hotels is manifested in the fact that, with loans secured from Legend Capital and other equity investment companies in 2012, the Pod Inn chain operating in mainland China since 2007 (which had 108 hotels in 2011) increased the number of its budget hotels to 300 in 2013 (Xiao 2013).

${ }^{16}$ Available from: <http://www.998.com/eng/About/default.aspx>. [15.02.2014]

Available from: <http://en.wikipedia.org/wiki/GreenTree_Inns>. [15.02.2014].
}

Another feature characterising the Chinese systems is that they are listed not only on the Shanghai Stock Exchange (SSE) and Hong Kong Stock Exchange (HKE), but also in New York. Moreover, as best proved by the former 7 Days Group Holdings Ltd. (operating as Plateno Hotels Group Ltd. since 2013), they largely fund their growth with inward capital. One such foreign company investing in hotel operators in mainland China is the Carlyle Investment Group (USA). According to Eric Zhang, Managing Director at Carlyle, 'With the acceleration of the country's urbanisation drive and an improvement in Chinese people's disposable income, customers will have more specific requirements and the coverage of high-end and economic hotels will have a bigger market space' (Xiao 2013). But recent years have shown that the domestic market is not big enough for Chinese hotel systems.

\section{References}

Alexander, N \& Lockwood, A 1996, 'Internationalisation: a comparison of the hotel and retail sectors', The Service Industries Journal, vol. 16, no. 4, pp. 458-473.

'China Lodging Group, Ltd.' Form 20-F (annual and transition report (foreign private issuer)). Filed 04/23/13 for the period ending 12/31/12. Available from: <http://www.otcmarkets. com/edgar/GetFilingPdf?FilingID=9234688>. [15.02.2014].

'China Lodging Group, Ltd.' Form 20-F (annual and transition report (foreign private issuer)). File 04/17/14 for the period ending 12/31/13. Available from: <http://files. shareholder.com/downloads/ABEA-40FHZ9/3582468975x 0x745423/0FBC91FC-DA35-429E-BCD7-62B82093F083/ Huazhu_2013_Annual_Report.pdf $>$. [10.10.2014].

Crawford-Welch, S. 1992, 'Competitive marketing strategies in the international hospitality industry' in International hospitality management: corporate strategy in practice, eds $\mathrm{R}$ Teare \& M. Olsen, London, John Wiley, pp. 95-109.

Formica, S 1996, 'Political risk analysis in relation to foreign direct investment: a view from the hospitality industry', Revue de Tourisme - The Tourist Review - Zeitschrift fur Fremdenverkehr, vol. 51, no. 4, pp. 15-23.

Kowalczyk, A 2006, 'East Asian hotel chains - dwarfs among giants?', Asia \& Pacific Studies, vol. 3, pp. 7-35, Faculty of Geography \& Regional Studies, Warsaw University.

Kowalczyk, A. 2007 'Systemy hotelowe - ich początki i ewolucja/ Hotel chains: an approach to their origin and evolution', Turyzm/Tourism, vol. 17 , no. 1/2, pp. 63-76.
Kowalczyk, A 2012, 'Globalizacja usług hotelarskich na przykładzie głównych systemów hotelowych świata', in Globalizacja i regionalizacja we współczesnym świecie. Księga jubileuszowa dedykowana Profesor Irenie Pietrzyk, ed E Molendowski, Uniwersytet Ekonomiczny w Krakowie, Kraków, pp. 561-575.

Littlejohn, D \& Roper, A 1991, 'Changes in international hotel companies' strategies', in International hospitality management: corporate strategy in practice, eds $\mathrm{R}$ Teare \& $\mathrm{M}$ Olsen, London, John Wiley \& Sons, pp. 194-212.

'Shanghai Jin Jiang International Hotels (Group) Company Limited. Annual report 2014', Shanghai Jin Jiang International Hotels (Group) Company Limited, Shanghai. Available from: $<$ (http://www.jinjianghotels.com.cn/UploadFiles/E_JJ14 AR.pdf>. [25.08.2015].

Shen, S 2008, 'China's booming budget hotels profit from no frills', Reuters, 16.01.2008. Available from: <http:// in.reuters.com/article/2008/01/16/us-china-budgethotelsidINSHA22099620080116>. [15.02.2014].

Xiao, C. 2013 'Carlyle checks into Chinese hotel sector', China Daily, 19.09.2013. Available from: <http://usa.chinadaily. com.cn/business/2013-09/19/content 16981187.htm>. [15.02.2014].

Xiaozhuo, L 2013, '7 Days economy hotel chain sold', China Daily, 18.07.2013. Available from: <http://usa.chinadaily. com.cn/business/2013-07/18/content_16795235.htm>. [15.02.2014].

\section{Internet Sources}

Available from: <http://en.wikipedia.org/wiki/7_Days_Inn>. [15.02.2014].

Available from: <http://en.wikipedia.org/wiki/GreenTree_Inns>. [15.02.2014].

Available from: <http://en.wikipedia.org/wiki/Home_Inn>. [15.02.2014].

Available from: <http://www.998.com/eng/About/default.aspx>. [15.02.2014].

Available from: <http://www.jinjianghotels.com.cn/en/Aboutus aspx?cid=18\&id=2>. [15.02.2014]
Available from: <http://www.plateno-hotels.cc/en/about-us> [25.08.2015].

Available from: $<$ http://phx.corporate-ir.net/phoenix. zhtml?c=203641\&p=irol-homeProfile>. [15.02.2014].

Available from: <http://www.referenceforbusiness.com/ history2/90/Hospitality-Franchise-Systems-Inc.html>. [03.03.2012] 